\title{
Recent declines in benthic macroinvertebrate densities in Lake Ontario'
}

\author{
Stephen J. Lozano, Jill V. Scharold, and Thomas F. Nalepa
}

\begin{abstract}
Surveys of benthic macroinvertebrates conducted in Lake Ontario during 1994 and 1997 revealed recent declines in populations of three major taxonomic groups: Oligochaeta, Sphaeriidae, and Diporeia spp. (Amphipoda), with the most drastic reductions occurring in the latter. Results from sediment measurements were used to classify deepwater sediments into three habitat zones. Densities of all three taxa declined in the shallowest $(12-88 \mathrm{~m})$ of the sediment zones between 1994 and 1997; the greatest changes in density were observed for Diporeia, which declined from 3011 to 145 individuals $\cdot \mathrm{m}^{-2}$, and for total benthic macroinvertebrates, which declined from 5831 to 1376 individuals $\cdot \mathrm{m}^{-2}$. Mean densities of Dreissena spp. in 1997 were highest in the shallowest zone, and the areas of greatest densities corresponded to areas of largest reductions in Diporeia populations. We believe that dreissenids are competing with Diporeia by intercepting the supply of fresh algae essential for Diporeia survival. A decline in macroinvertebrate densities, especially populations of an important food item such as Diporeia, in Lake Ontario sediments at depths of 12-88 m may have a detrimental impact on the benthic food web.
\end{abstract}

Résumé : Des inventaires des macroinvertébrés benthiques du lac Ontario en 1994 et 1997 ont révélé des déclins récents dans les peuplements de trois importants groupes taxonomiques, les oligochètes, les sphaeriidés et, de façon encore plus marquée, les amphipodes Diporeia spp. Des analyses de sédiments ont permis de classifier les substrats de la zone profonde en trois types d'habitats. Les densités des trois taxons ont diminué dans la zone la moins profonde (12-88 m) de 1994 à 1997; les déclins les plus importants se sont manifestés chez les Diporeia, don’t les densités sont passées de 3011 à 145 individus $\cdot \mathrm{m}^{-2}$, et dans le peuplement total de macroinvertébrés qui a baissé de 5831 à 1376 individus $\mathrm{m}^{-2}$. Les densités moyennes les plus élevées de Dreissena spp. en 1997 ont été retrouvées dans la zone la moins profonde, leurs densités maximales correspondant aux régions des plus forts déclins des peuplements de Diporeia. Nous croyons que les dreissénidés font compétition aux Diporeia en leur bloquant l'accès aux algues fraîches nécessaires à leur survie. Un déclin des densités des macroinvertébrés, particulièrement celui d'une ressource alimentaire importante comme les peuplements de Diporeia, dans les sédiments du lac Ontario aux profondeurs 12-88 m peut avoir un effet néfaste sur le réseau alimentaire benthique.

[Traduit par la Rédaction]

\section{Introduction}

The deepwater, benthic macroinvertebrate community of the Great Lakes is dominated by a few species of organisms. The cold-stenotherm association includes Oligochaeta, Sphaeriidae, and Diporeia spp. (Cook and Johnson 1974). Two species of oligochaetes, Stylodrilus heringianus and Limnodrilus hoffmeisteri, are found throughout the offshore regions and may account for $10-20 \%$ of the total benthic population density (Mozley and Howmiller 1977). Members of the bivalve family Sphaeriidae are usually found in waters less than $90 \mathrm{~m}$ deep and account for $5-15 \%$ of the total benthic population density. The amphipod Diporeia spp. (for- merly Pontoporeia hoyi) is the most abundant macroinvertebrate (Mozley and Howmiller 1977; Nalepa 1991) in the Great Lakes. In deeper water habitats, it accounts for $40-70 \%$ of the total density of benthic organisms (Nalepa 1991), reaching greatest densities at depths below the summer thermocline in waters 30-60 m deep.

In the Great Lakes, Diporeia is found in greatest numbers in soft or fine sediments and in sand overlain with a thin layer of detritus (Marzolf 1965). An important source of food for Diporeia arrives in the spring and fall when water conditions favor diatom blooms and subsequent settling of diatoms onto the sediments (Saether 1980). Diporeia depends on settling algae for growth and reproduction, storing

Received April 7, 1999. Accepted November 20, 2000. Published on the NRC Research Press Web site on February 28, 2001.

$\mathrm{J} 15099$

S.J. Lozano ${ }^{2,3}$ and J.V. Scharold. U.S. Environmental Protection Agency, Mid-Continent Ecology Division, 6201 Congdon Blvd., Duluth, MN 55804, U.S.A.

T.F. Nalepa. Great Lakes Environmental Research Laboratory, NOAA, 2205 Commonwealth Blvd., Ann Arbor, MI 48105, U.S.A.

${ }^{1}$ The information in this document has been funded wholly (or in part) by the U.S. Environmental Protection Agency. It has been subjected to review by the National Health and Environmental Effects Research Laboratory and approved for publication. Approval does not signify that the contents reflect the views of the Agency, nor does mention of trade names or commercial products constitute endorsement or recommendation for use.

${ }^{2}$ Corresponding author (e-mail: lozano@glerl.noaa.gov).

${ }^{3}$ Present address: Great Lakes Environmental Research Laboratory, NOAA, 2205 Commonwealth Blvd., Ann Arbor, MI 48105, U.S.A. 
Fig. 1. Location of sampling stations in Lake Ontario in (a) 1994 and (b) 1997.

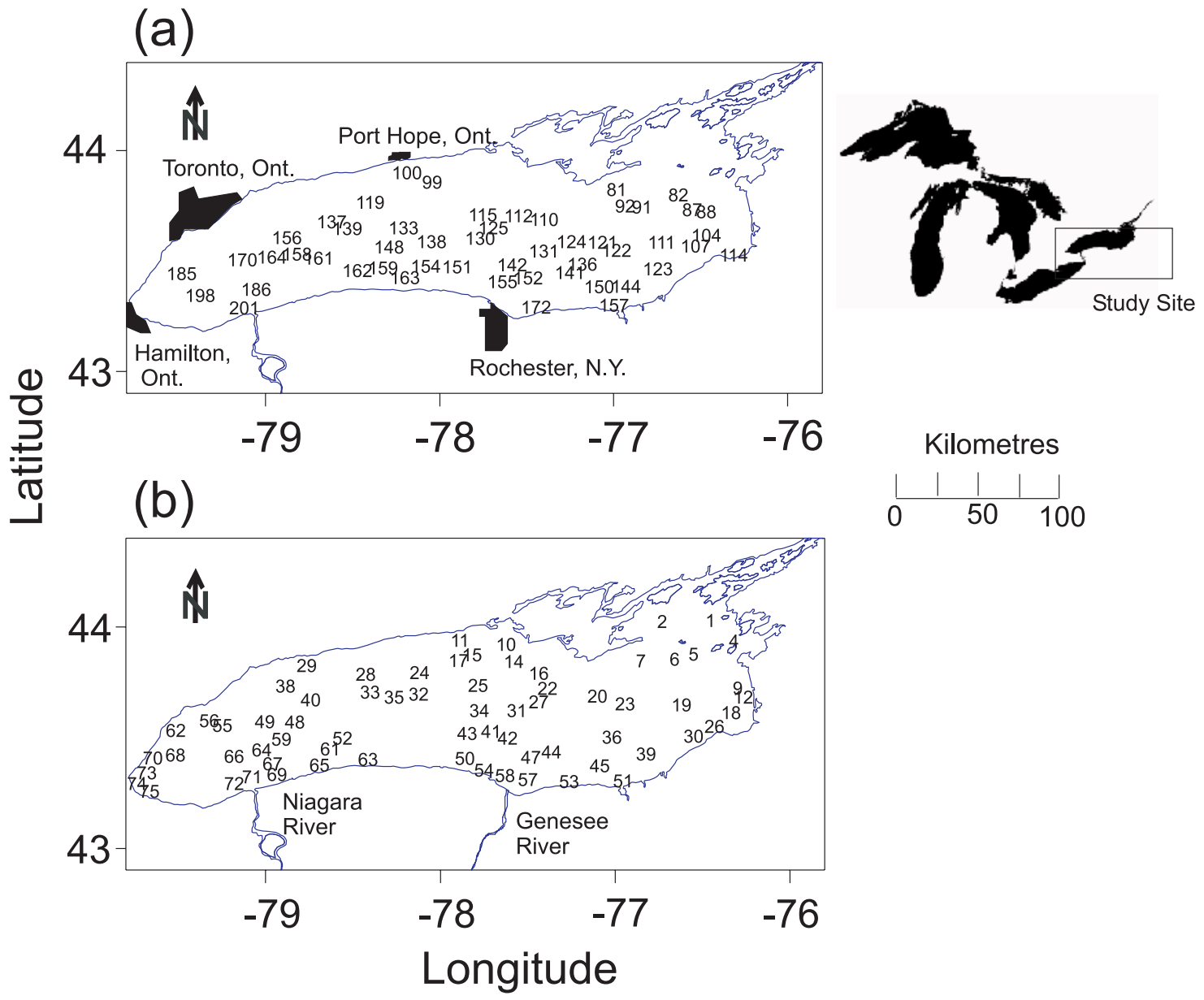

the assimilated energy as lipid. Lipid levels of Diporeia are high compared with those of other Great Lakes benthic macroinvertebrates and can account for up to $50 \%$ of the amphipods' dry weight after the spring diatom bloom (Gardner et al. 1985). It has been estimated that within deeper water habitats of the Great Lakes, $23 \%$ of the total annual carbon production from phytoplankton is consumed by this organism (Flint 1986). Fitzgerald and Gardner (1993) reported that Diporeia ingested $61 \%$ of the spring diatom bloom in Lake Michigan. A large portion of Diporeia biomass is transferred up the food chain to forage fish. Diporeia is the dominant food organism of the slimy sculpin in Lake Ontario (Owens and Weber 1995) and most other fish species feed on Diporeia at some stage in their life cycle (Mozley and Howmiller 1977). Because of the importance of benthic macroinvertebrates and particularly Diporeia in fish diets, changes in the status of Diporeia or the other two major taxa could have dramatic effects on fish production in the Great Lakes.

Colonization by the dreissenid mussels Dreissena polymorpha and Dreissena bugensis is probably one of the more ecologically important events to occur in the Great Lakes during the last decade (MacIsaac 1996). Since their discovery in 1988, dreissenids have colonized both soft and hard substrates to depths of $130 \mathrm{~m}$ (Mills et al. 1993) and reached densities of $340000 \cdot \mathrm{m}^{-2}$ in some areas (Leach 1993). Because of high densities, widespread distribution, and high filtering rates, Dreissena populations can filter large volumes of water and have the capacity to decrease algal biomass (Holland 1993; Fahnenstiel et al. 1995). Therefore, this diversion of algal production into dreissenid tissue and biodeposits may deprive Diporeia and other deepwater macroinvertebrates of food settling from the water column.

In this study, we examined changes in densities of Diporeia, Oligochaeta, and Sphaeriidae in Lake Ontario between 1994 and 1997 and relate these changes to those observed over the past three decades. We present evidence that all three taxonomic groups have declined in density in waters between 12 and $88 \mathrm{~m}$ at a time when Dreissena densities were increasing.

\section{Methods}

\section{Macroinvertebrate sampling design and processing}

Benthic samples were collected from Lake Ontario in late August 1994 and early September 1997 at 55 and 75 stations, respectively (Fig. 1). Sampling depths ranged from 12 to $213 \mathrm{~m}$. Station locations in 1994 and 1997 were based on a randomized design using a systematic grid (Stevens 1997). Locations in 1994 were then classified into habitat zones based on principal components analysis (PCA) of physical and chemical data (see below). Because only a subset of physical and chemical measurements were taken in 1997, 


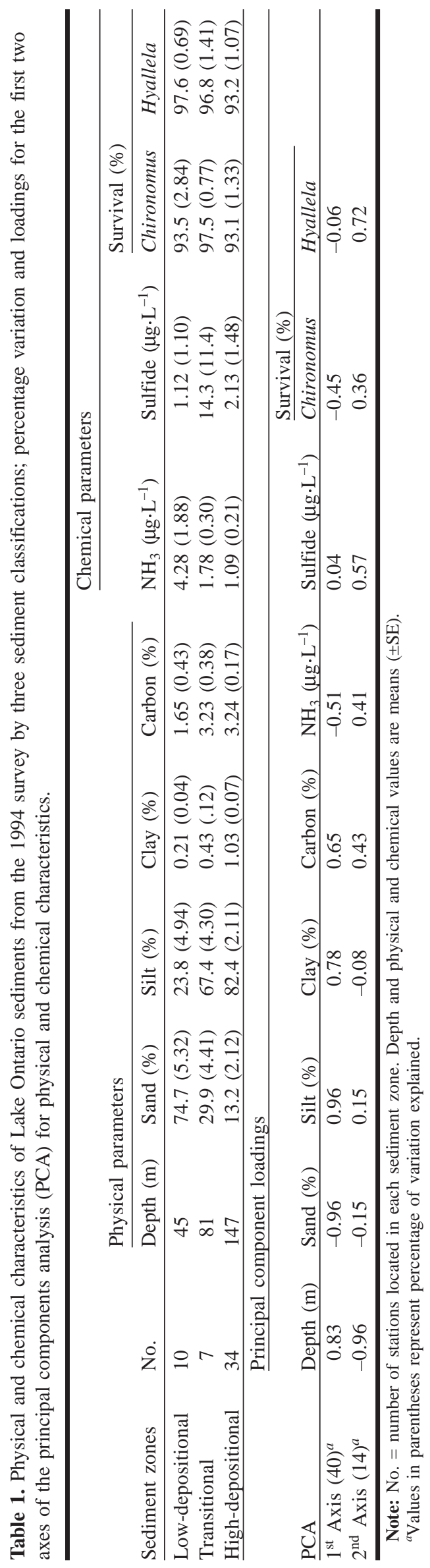

classification of these locations was based on grain size and depth, two of the most important discriminating measurements as determined by PCA. Position for sampling was determined by a Loran $\mathrm{C}$ navigation.

At each station, three samples were taken with a Ponar grab (area $=0.048 \mathrm{~m}^{2}$ ); the samples were pooled into a single sample, placed into an elutriation device, and washed through a nylon sleeve with a 500- $\mu$ m opening (Mozley and Howmiller 1977). The residue retained was preserved in 5\% formalin containing rose bengal stain. In the laboratory, organisms were initially removed from samples under a dissecting microscope and identified into major taxonomic groups. Later, organisms were identified to the lowest possible taxonomic level. Dreissena were counted and identified to species in 1997 but not in 1994.

\section{Sediment collection and analysis}

In 1994, an additional Ponar grab sample was collected from each station and sediment from the top $2 \mathrm{~cm}$, assumed to represent the biologically active zone, was placed into clean glass containers and kept at $5^{\circ} \mathrm{C}$. These sediments were analyzed for grain size, organic carbon, ammonia, sulfide, and relative toxicity. Standard methods for grain size analysis and total organic carbon were followed (ASTM 1991). Results for grain size were reported as percentage clay $(<4 \mu \mathrm{m})$, silt $(4-60 \mu \mathrm{m})$, and sand $(>60 \mu \mathrm{m})$. Ten-day toxicity tests for Hyalella azteca and Chironomus tentans were conducted according to standard methods (Ingersoll and Nelson 1990). Results were reported as percentage survival of organisms. Measurements of pore-water ammonia and sulfide concentrations followed methods of Ankley et al. (1993).

\section{Statistical analysis}

A principal components analysis (PCA, Wilkinson 1996) was performed using physical and chemical characteristics of sediments collected in 1994 to identify different macroinvertebrate habitat zones. Variables included in the analysis were percentage survival of Hyallela azteca and Chironomus tentans in toxicity tests, percentage sand, silt, clay, and carbon, depth, ammonia, and sulfide. Mean population densities in each zone (numbers of individuals. $\mathrm{m}^{-2}$ ) and between year(s) were compared with analysis of variance (ANOVA) and Tukey's test $(p \leq 0.05)$ using densities at each station as replicates (Wilkinson 1996). Water depth was included as a covariate term. Variance stabilizing transformations were used prior to data analysis. An arcsine - square root transformation was used for percentage data and a log transformation was used for macroinvertebrate density data.

\section{Results}

\section{Sediment analysis}

Results from PCA indicate that the first principal component accounted for $40 \%$ of total variability with depth, $\%$ sand, and \% silt being the variables that correlated most highly with the first axis (Table 1). In general, sand and silt accounted for the majority of dry sediment mass at all stations, with clay comprising $<2 \%$ of the remaining sediment mass at each site. Thus deepwater stations with high amounts of silt and clay are located to the right of where the PC1 and PC2 axes intersect (Fig. 2). As a result, a strong negative correlation exists between sand and silt such that areas with high $\%$ sand have low $\%$ silt, and vice versa. The second principal component accounted for $14 \%$ of the variability with percentage survival of $H$. azteca, ammonia, and sulfide levels being most highly correlated with the second axis.

The results of PCA for habitat characteristics with the 1994 data revealed three groupings of stations (Table 1, Fig. 2). 
Fig. 2. Classification of Lake Ontario sediments by principal components analysis (PCA) for physical and chemical parameters, 1994. Variables used in PCA included depth, $\mathrm{NH}_{3}$, and sulfide $\left(\mu \mathrm{g} \cdot \mathrm{L}^{-1}\right)$, survival of Hyalella azteca and Chironomus tentans (percentage survival), and percentage sand, silt, clay, and carbon.

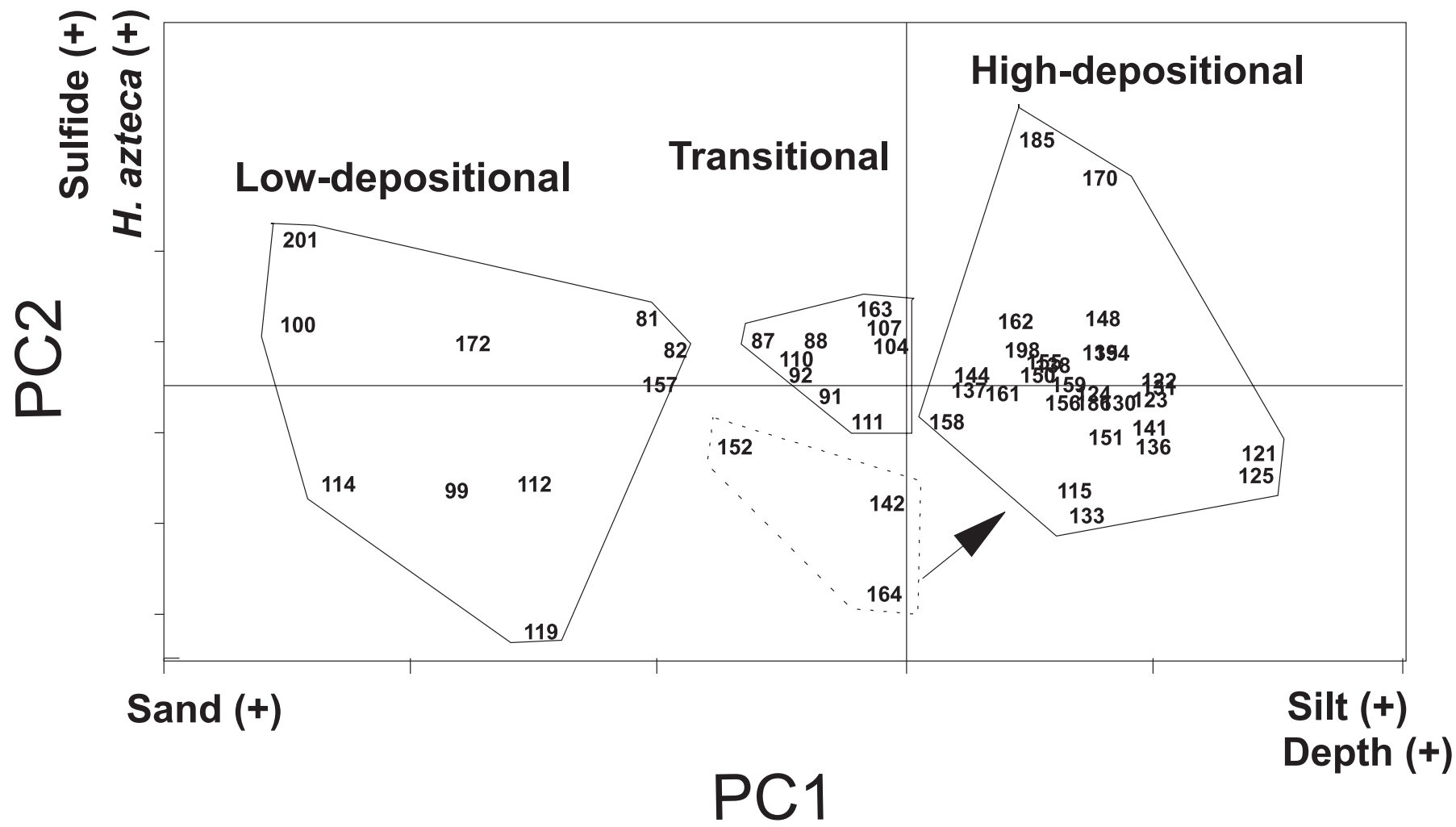

The three groupings were identified as low-depositional, transitional, and high-depositional areas (Table 1, Figs. 1, 2). The low-depositional zone included stations with a high ratio of sand to silt and low \% carbon; these stations were generally located in shallower, nearshore regions $(12-88 \mathrm{~m})$. The high-depositional zone was characterized by stations with sediments of a higher ratio of silt to sand and high \% clay relative to sediments from other stations. High-depositional stations were deeper (90-213 m) and located centrally in the lake. The transitional zone included stations with sediments having a mixture of sand and silt and \% clay that was intermediate between low- and high-depositional stations. Depths in this zone were intermediate $(63-91 \mathrm{~m})$ and stations were located between the low-depositional and high-depositional zone (Fig. 1, 2). Three stations (stations 142, 152, and 164) were intermediate in sand and silt but located in deeper water, i.e., greater than $134 \mathrm{~m}$ (Fig. 1). These stations were located on the Whitby-Olcott and Scotch Bonnet sills (Thomas et al. 1972) that separate the Lake Ontario basin into three deepwater high-depositional zones. For macroinvertebrate analysis, stations located on the sills were placed in the high-depositional group.

\section{Macroinvertebrate densities}

Three taxa, Diporeia spp., Oligochaeta, and Sphaeriidae, comprised 91-99\% of all macroinvertebrates collected in 1994 and 1997. There were significant differences for major taxa within sediment zones. In the low-depositional zone, densities of Diporeia were most abundant at depths greater than $42 \mathrm{~m}$ in 1994 but no pattern was discernable along the depth gradient sampled in 1997 (Table 2). At stations where Diporeia were abundant, densities averaged $6363 \cdot \mathrm{m}^{2}$ in 1994 compared with $954 \cdot \mathrm{m}^{2}$ in 1997 . Further, the percentage of stations where no or very few Diporeia $\left(<5 \mathrm{~m}^{2}\right)$ were found increased from $40 \%$ in 1994 to $84 \%$ in 1997. In the transitional and high-depositional zones, there was little association between depth and Diporeia densities in 1994 or 1997, and at stations where Diporeia were abundant, densities were comparable. There were no apparent patterns between densities of Oligochaeta or Sphaeriidae and depth within any of the three sediment zones.

Results from ANOVA of mean densities with main effects of differences between years and sediment zones were statistically significant for all three taxa and total macroinvertebrate density with $p$-values of $0.001-0.008$. The covariate term water depth was never a significant factor in the ANOVA with $p$-values of 0.146-0.504. Densities of Diporeia, Oligochaeta, and Sphaeriidae and total macroinvertebrates were significantly (Tukey's test) lower in 1997 compared with 1994 in the low-depositional zone (Table 3), with percentage declines of $95,61,45$, and $76 \%$, respectively. Densities of Oligochaeta, but not Diporeia and Sphaeriidae, were significantly lower in 1997 compared with 1994 in the high-depositional zone, with a percentage decline of $58 \%$. Another general trend, although not always statistically significant, was for densities to be lower in the high-depositional zone compared with the other two sediment zones for all three taxa and total macroinvertebrates (Table 3). In the transitional zone, there were no significant differences in densities of the three taxa and total abundance 
Table 2. Densities (no. $\mathrm{m}^{-2}$ ) of four major taxa in Lake Ontario are ordered by depth and grouped by sediment zones.

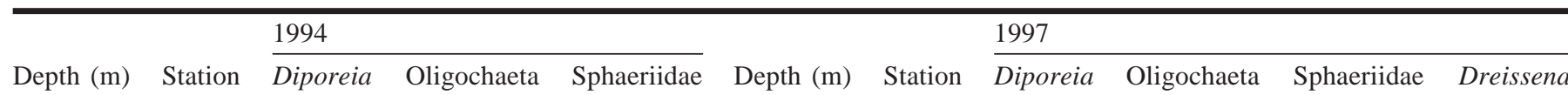

\section{Low-depositional zone}

$\begin{array}{lrrr}12 & 114 & 0 & 530 \\ 12 & 201 & 185 & 5671 \\ 20 & 172 & 0 & 5662 \\ 23 & 157 & 0 & 525 \\ 42 & 81 & 4 & 3907 \\ 48 & 100 & 7528 & 1277 \\ 59 & 82 & 2054 & 1369 \\ 59 & 99 & 6473 & 1036 \\ 83 & 112 & 6983 & 1036 \\ 88 & 119 & 5952 & 1603\end{array}$

\section{Transitional zone}

$\begin{array}{lrl}70 & 163 & 1322 \\ 75 & 88 & 5267 \\ 76 & 87 & 6202 \\ 82 & 91 & 7778 \\ 82 & 92 & 7890 \\ 89 & 185 & 4556 \\ 96 & 110 & 4763\end{array}$

\section{High-depositional zone}

$\begin{array}{rrrrrrrrr}93 & 198 & 2976 & 440 & 108 & 100 & 67 & 1760 & 280 \\ 100 & 186 & 5110 & 511 & 174 & 112 & 25 & 2636 & 107 \\ 103 & 144 & 4 & 430 & 297 & 112 & 33 & 773 & 129 \\ 114 & 107 & 0 & 1783 & 332 & 122 & 66 & 1729 & 196 \\ 115 & 104 & 0 & 610 & 263 & 125 & 64 & 996 & 364 \\ 117 & 159 & 1848 & 166 & 39 & 130 & 48 & 1107 & 53 \\ 119 & 137 & 2407 & 199 & 17 & 134 & 19 & 533 & 178 \\ 122 & 155 & 3062 & 922 & 168 & 134 & 31 & 2369 & 142 \\ 125 & 115 & 3618 & 407 & 34 & 136 & 49 & 778 & 18 \\ 133 & 154 & 2692 & 345 & 82 & 138 & 23 & 1062 & 111 \\ 134 & 139 & 426 & 270 & 4 & 138 & 59 & 1831 & 360\end{array}$

960
960
1069
501
681
319
184

831
771
952
646
573
134
138

$$
74
$$$$
75
$$$$
76
$$$$
80
$$$$
81
$$$$
83
$$$$
87
$$$$
90
$$$$
91
$$$$
22
$$

\begin{tabular}{|c|c|c|c|c|c|c|}
\hline 155 & 14 & 1 & 0 & 0 & 0 & 1511 \\
\hline 237 & 15 & 15 & 276 & 800 & 516 & 920 \\
\hline 103 & 18 & 75 & 0 & 4129 & 467 & 93 \\
\hline 22 & 19 & 51 & 0 & 342 & 0 & 2587 \\
\hline 947 & 20 & 74 & 0 & 2071 & 280 & 173 \\
\hline 1477 & 23 & 63 & 0 & 2218 & 4 & 2133 \\
\hline 588 & 25 & 30 & 0 & 187 & 0 & 5640 \\
\hline 327 & 26 & 2 & 4 & 116 & 0 & 49 \\
\hline 207 & 26 & 29 & 4 & 111 & 316 & 22 \\
\hline \multirow[t]{22}{*}{172} & 27 & 4 & 0 & 111 & 0 & 9 \\
\hline & 27 & 26 & 0 & 53 & 0 & 258 \\
\hline & 27 & 62 & 0 & 369 & 440 & 4 \\
\hline & 29 & 58 & 0 & 3280 & 0 & 3480 \\
\hline & 31 & 10 & 0 & 0 & 0 & 2022 \\
\hline & 31 & 54 & 0 & 2062 & 4 & 1987 \\
\hline & 33 & 12 & 0 & 173 & 18 & 13 \\
\hline & 37 & 11 & 0 & 284 & 58 & 3964 \\
\hline & 38 & 9 & 0 & 133 & 9 & 147 \\
\hline & 40 & 53 & 4 & 236 & 378 & 1089 \\
\hline & 40 & 73 & 0 & 893 & 462 & 0 \\
\hline & 43 & 6 & 0 & 378 & 84 & 0 \\
\hline & 45 & 70 & 1138 & 2191 & 2431 & 18 \\
\hline & 46 & 7 & 0 & 409 & 40 & 0 \\
\hline & 49 & 5 & 0 & 409 & 0 & 9 \\
\hline & 51 & 14 & 453 & 649 & 649 & 111 \\
\hline & 56 & 16 & 1564 & 711 & 449 & 187 \\
\hline & 57 & 57 & 0 & 542 & 204 & 36 \\
\hline & 58 & 18 & 0 & 796 & 169 & 53 \\
\hline & 62 & 17 & 1058 & 449 & 307 & 311 \\
\hline & 64 & 65 & 0 & 849 & 0 & 53 \\
\hline & 69 & 69 & 0 & 2053 & 142 & 756 \\
\hline
\end{tabular}$$
\begin{aligned}
& 22 \\
& 71 \\
& 72
\end{aligned}
$$

$\begin{array}{lrrrr}22 & 0 & 520 & 98 & 0 \\ 71 & 3640 & 2009 & 200 & 13 \\ 72 & 1729 & 764 & 231 & 0 \\ 28 & 3751 & 809 & 142 & 9 \\ 38 & 6280 & 1307 & 4 & 0 \\ 24 & 5364 & 849 & 111 & 4 \\ 68 & 3453 & 227 & 98 & 0 \\ 56 & 8813 & 1324 & 316 & 0 \\ 50 & 0 & 320 & 93 & 0 \\ 20 & 436 & 209 & 164 & 0\end{array}$


Table 2 (concluded).

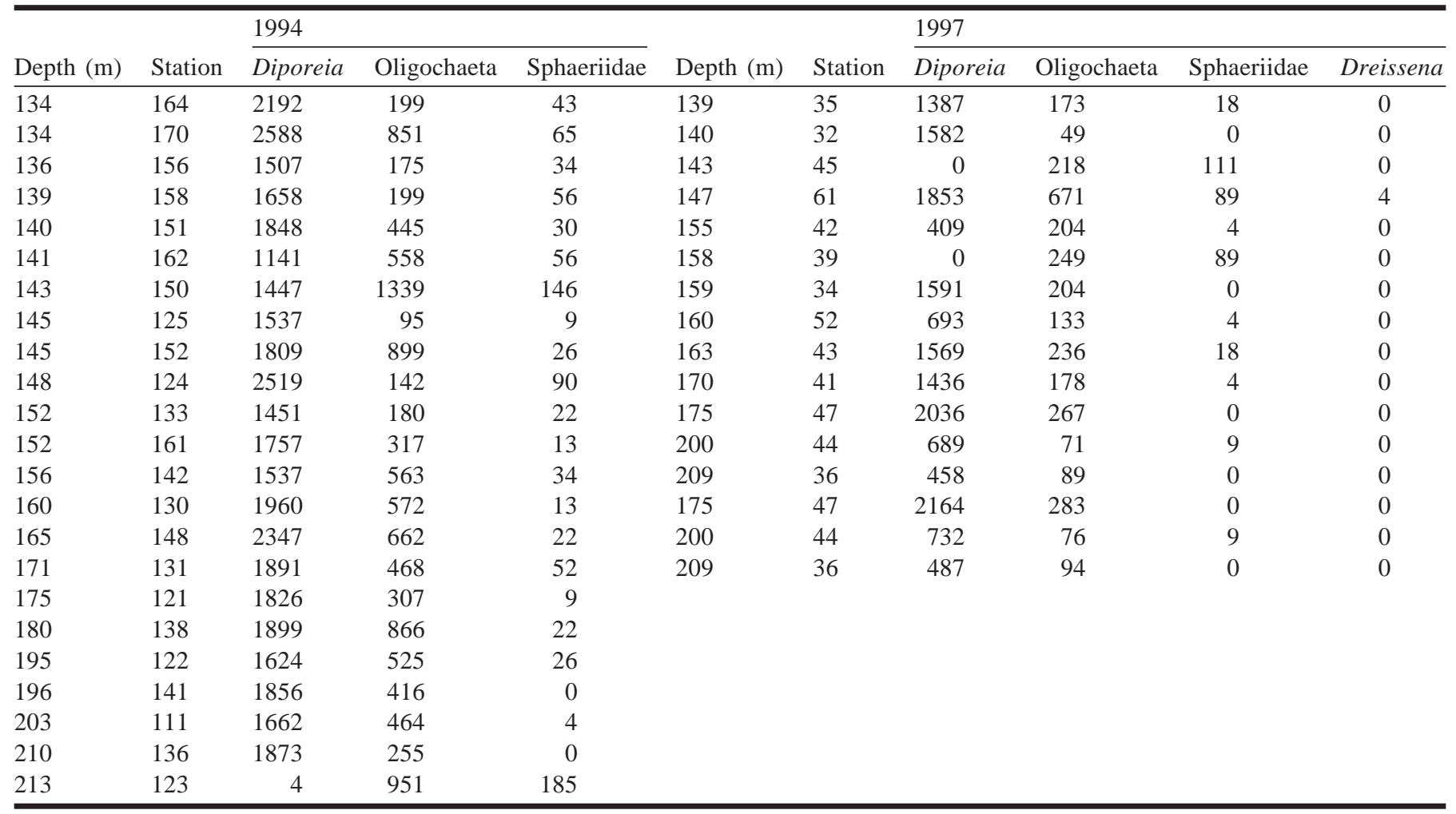

Table 3. Comparison between densities $\left(\right.$ no. $\cdot \mathrm{m}^{-2}$ ) of three major taxa and total invertebrate densities in Lake Ontario by year and three sediment zones.

\begin{tabular}{|c|c|c|c|c|c|c|}
\hline \multirow[b]{2}{*}{ Taxa } & \multicolumn{2}{|c|}{ Low-depositional zone } & \multicolumn{2}{|c|}{ Transitional zone } & \multicolumn{2}{|c|}{ High-depositional zone } \\
\hline & 1994 & 1997 & 1994 & 1997 & 1994 & 1997 \\
\hline No. of stations & 10 & 31 & 7 & 10 & 34 & 27 \\
\hline Oligochaeta & $2125(603) a$ & 830 (185) bc & $631(121) a b c$ & $874(182) a b$ & $484(58) b$ & $203(27) \mathrm{c}$ \\
\hline Sphaeriidae & 437 (150) a & $240(81) \mathrm{bc}$ & $596(127) \mathrm{a}$ & $146(27) \mathrm{ab}$ & 75 (15) bc & $35(8.8) \mathrm{c}$ \\
\hline Total macroinvertebrate & 5831 (1013) a & $1376(282) b$ & 6898 (902) a & $4358(1055) \mathrm{ac}$ & $2514(181) \mathrm{ac}$ & 1689 (197) c \\
\hline
\end{tabular}

Note: Values are means $( \pm \mathrm{SE})$. Values followed by a different letter are significantly different (ANOVA followed by Tukey’s test, $p \leq 0.05$ on logtransformed data). Total macroinvertebrate density does not include densities of Dreissena spp.

between years and other sediment zones. The lack of significant differences may be partially due to the small number of stations located in this zone.

The spatial distribution pattern of Diporeia was different between 1994 and 1997, especially in the low-depositional zone. In 1994, highest population densities were found at stations located along the northern shoreline and at the far eastern end of the lake (Fig. 3a). A contiguous zone of stations with population densities of $<4$ individuals $\cdot \mathrm{m}^{-2}$ occurred along the southeastern shore between the Genessee River outlet and Mexico Bay. In 1997, the number of stations with population densities of $<4$ individuals $\cdot \mathrm{m}^{-2}$ increased and these stations extended all around the lake. The exception was Station 62 near Toronto where densities were $1311 \cdot \mathrm{m}^{-2}$. In some areas, this depauperate zone extended as far as $26 \mathrm{~km}$ offshore and to a depth of $160 \mathrm{~m}$ and encompassed over $40 \%$ of the total area of the lake. The most severe effect was along the southern and eastern shoreline from the outlet of the Niag- ara River to Point Petre, where Diporeia were absent from samples collected in waters $140 \mathrm{~m}$ deep or less.

In 1994 , there were large numbers $\left(>5000 \cdot \mathrm{m}^{-2}\right)$ of oligochaetes near the mouths of the Niagara (Station 201) and Genessee (Station 172) rivers and along Point Petre (Station 81, Fig. 3b). Stylodrilus heringianus was the most abundant oligochaete at these stations, accounting for over $30 \%$ of the total number. In 1997, the spatial pattern of Oligochaeta was similar to 1994 but with lower numbers in the lowdepositional and high-depositional zones. Relatively high population densities of Sphaeriidae were present at stations located near the Kingston basin (Fig. 3c) in 1994. In 1997, the spatial pattern of Sphaeriidae was different from 1994 with fewer organisms near the eastern end of the lake.

Ponar grab samplers were used to estimate densities of dreissenids in 1997. Although dreissenids were present in 1994, the mussels were not collected or counted. The efficiency of this sampler for collecting attached mussels has 
Fig. 3. Distribution and density (no. $\mathrm{m}^{-2}$ ) of (a) Diporeia, (b) Oligochaeta, and (c) Sphaeriidae in 1994 and 1997. Kingston basin was not sampled in 1994 (hatched area on map).
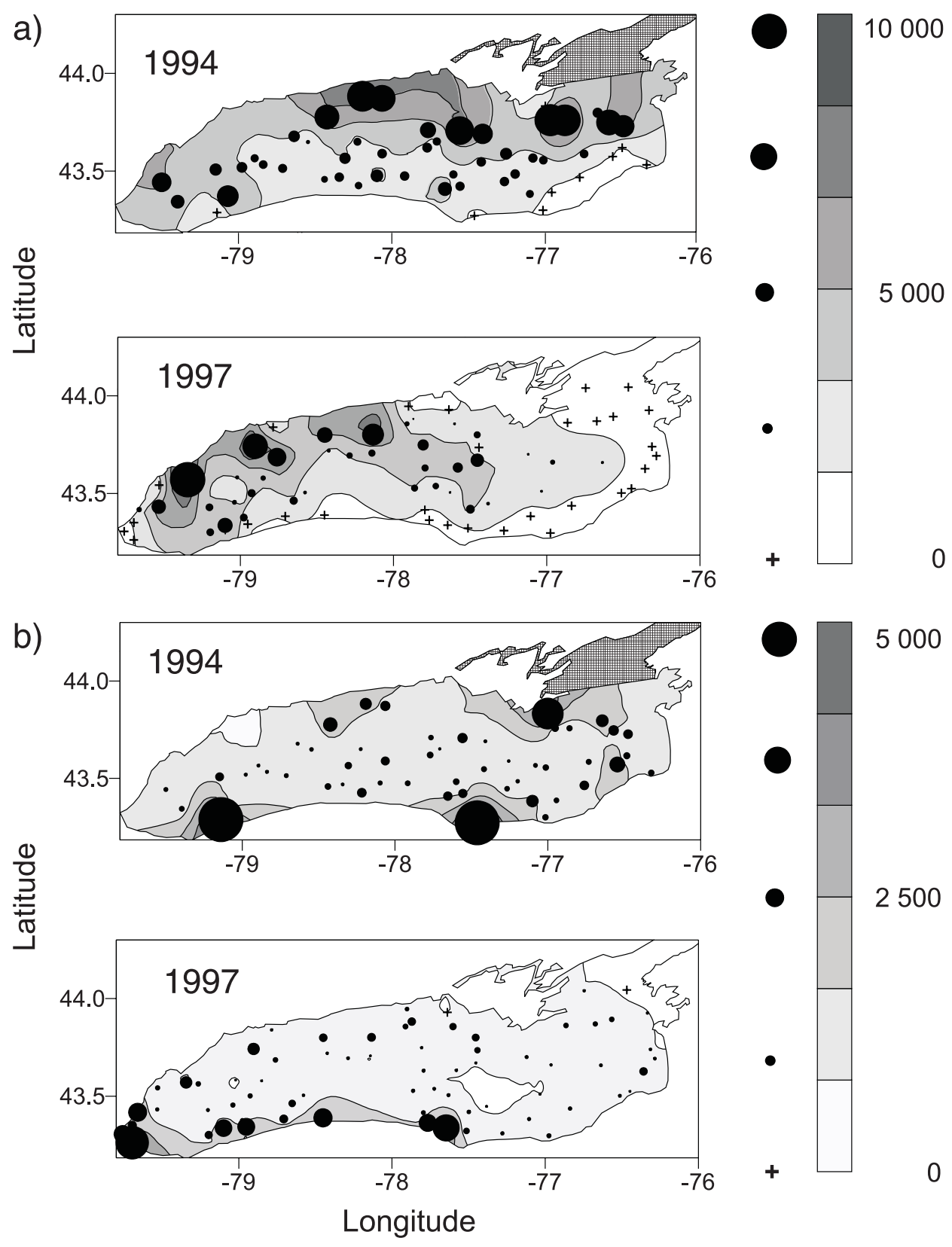

not been quantified so our results are a relative measure of population density and distribution. Mean densities of Dreissena polymorpha and D. bugensis in 1997 were highest in the low-depositional zone, intermediate in the transitional zone, and lowest in the high-depositional zone (Table 4). Neither species of Dreissena was abundant in waters deeper than $70 \mathrm{~m}$. Stations along the south shore from the outlet of the Niagara River to Mexico Bay had the largest numbers of Dreissena in waters less than $40 \mathrm{~m}$ deep (Fig. 4). There were also large numbers of Dreissena near Port Hope, Ontario, and in the Kingston basin. Species richness (mean number of species $\cdot$ site $^{-1}$ ) in waters $<40 \mathrm{~m}$ was greater at stations where Dreissena were present $(10.1 \pm 0.4$ (mean \pm SE), $t$ test, $p<0.05)$ compared with stations where Dreissena were absent (6.4 \pm 0.3$)$. Several species of Naididae (Chaetogaster diaphanus, Ophidonais serpentina, Stylaria lacustris, Vejdovskyella intermedia), Tubificidae (Potamothrix moldaviensis, $P$. vejdovskyi, Rhyacodrilus coccineus, Spirosperma ferox), and Chironomidae (Heterotrissocladius sp., Chironomus sp., Cryptochironomus sp., Paracladopelma sp., Paralauterborniella sp., Tribelos sp., Micropsectra sp., Tanytarsus sp.) were more abundant or only found in stations where dreissenids were present.

\section{Discussion}

Our data suggest a large change in total and relative density of the macroinvertebrate community in Lake Ontario for areas of the lake deeper than $12 \mathrm{~m}$. If Dreissena spp. are excluded from population estimates, our data indicate a major 
Fig. 3 (concluded).

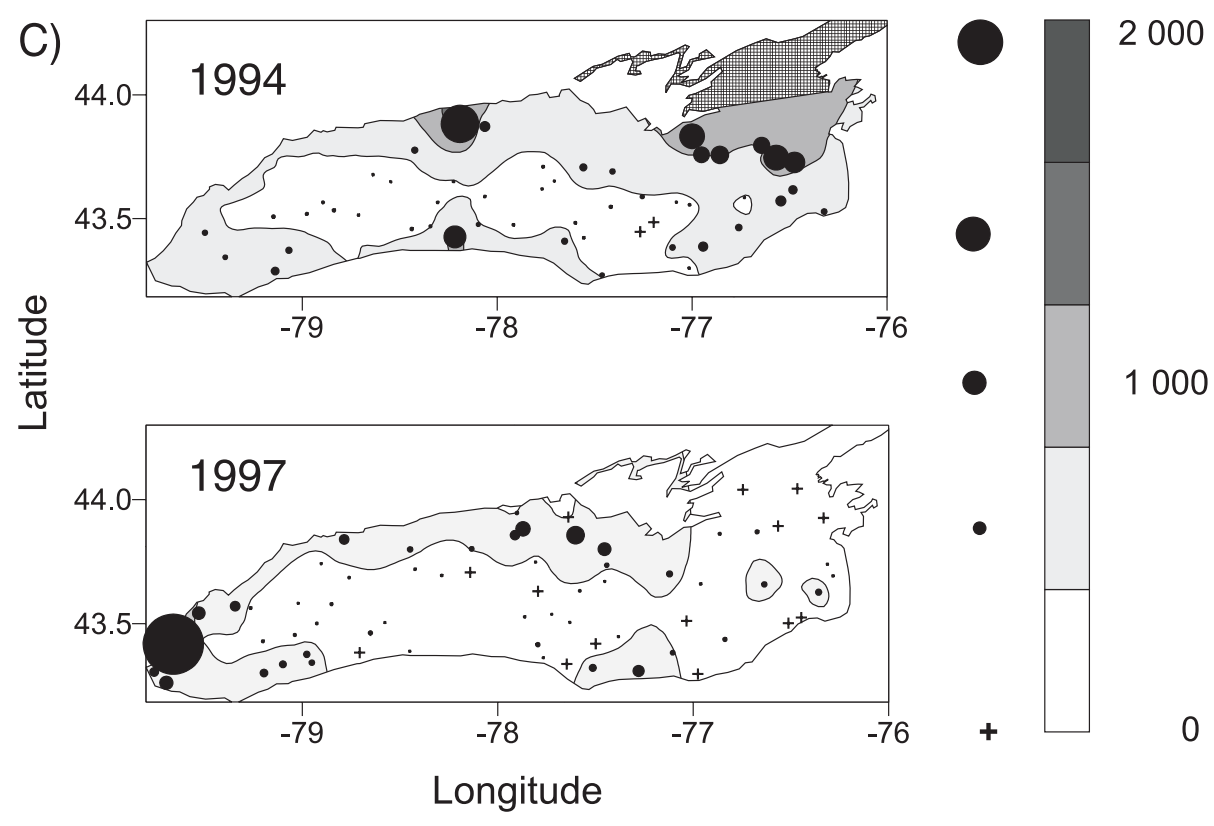

Table 4. Comparison between densities $\left(\right.$ no. $\cdot \mathrm{m}^{-2}$ ) of two species of Dreissena at three sediment zones.

\begin{tabular}{llll}
\hline & Low-depositional zone & Transitional zone & High-depositional zone \\
\hline No. of stations & 31 & 10 & 27 \\
Dreissena polymorpha & $357(195) \mathrm{a}$ & $0.4(0.4) \mathrm{bc}$ & $0(0) \mathrm{bc}$ \\
Dreissena bugensis & $535(174) \mathrm{a}$ & $2.2(1.2) \mathrm{bd}$ & $0.3(0.2) \mathrm{bd}$ \\
\hline
\end{tabular}

Note: Values are means $( \pm \mathrm{SE})$. Values followed by a different letter are significantly different (ANOVA followed by Tukey's test, $p \leq 0.05$ on log-transformed data).

decline in total macroinvertebrate densities between 1994 and 1997 in the low-depositional zone (12-88 m). Our results contrast those summarized by Nalepa (1991), who found no change in macroinvertebrate densities in shallow waters (10-35 m) between 1964 and 1988 and an increase in numbers of Diporeia in the Kingston basin. To allow comparisons to these earlier studies, we grouped our densities of Diporeia, Oligochaeta, and Sphaeriidae by the three depth intervals (Table 5) used by Nalepa (1991) for the two Lake Ontario surveys and tested for differences between years (analysis of variance, ANOVA, Tukey's test, $p<0.05$ ) in each depth interval. These comparisons are important because the surveys of Hiltunen (1969) and Nalepa and Thomas (1976) were completed before the invasion of Dreissena.

In the shallow depth interval, Diporeia, Oligochaeta, and Sphaeriidae were significantly lower in 1997 compared with densities found in 1964 and 1972 (Table 5). Mean densities of Diporeia were at least 130 times greater in 1964 and 1972 than in 1997, while mean densities of Sphaeriidae and Oligochaeta were at least nine times greater in 1964 and 1972 than in 1997. The mean density of Diporeia in 1994 was $40 \cdot \mathrm{m}^{-2}$ but the lack of statistically significant differences compared with earlier surveys is partially due to the small number of stations $(n=4)$ sampled in the shallow depth interval $(10-35 \mathrm{~m})$. In the intermediate depth interval, densities of Diporeia were significantly greater in 1972 and 1994 $\left(2131-4537 \cdot \mathrm{m}^{-2}\right)$ than in $1997\left(1282 \cdot \mathrm{m}^{-2}\right)$. Mean densities of Diporeia were much greater in $1964\left(9077 \cdot \mathrm{m}^{-2}\right)$ than in
1997 but the lack of statistical significance is also partially due to the small number of stations $(n=2)$ sampled in the intermediate depth interval $(36-90 \mathrm{~m})$ in 1964. In the deepest depth interval, results were mixed. Densities of Diporeia were variable but never significantly different between years. Densities of Oligochaeta and Sphaeriidae were significantly greater in 1964 than in 1972, 1994, and 1997 but there were no consistent trends after 1972. The spatial distribution of stations where Diporeia were absent in Lake Ontario sediments was similar in 1964 and 1972, i.e., the area extended along the south shore from the Niagara River eastward to Rochester, N.Y. (Hiltunen 1969; Nalepa and Thomas 1976). In 1997, we found the area where Diporeia was absent to have expanded to all areas around the lake in waters between 10-40 $\mathrm{m}$ and down to a depth of $140 \mathrm{~m}$ in the zone from the Niagara River eastward and northward to Point Petre, Ont. In addition to whole-lake surveys, Nalepa (1991) also provided a compilation of Lake Ontario benthic studies showing trends from a nearshore area (Kingston basin) of Lake Ontario before the invasion of Dreissena.

Between 1964 and 1988, Diporeia densities in the Kingston basin (28-35 m) of Lake Ontario were variable. Populations fluctuated between $3000 \cdot \mathrm{m}^{-2}$ and $10000 \cdot \mathrm{m}^{-2}$ during the period of 1964 to 1984 and then rose to $13900 \cdot \mathrm{m}^{-2}$ by 1988 . We found a mean population of Diporeia of less than $1 \cdot \mathrm{m}^{-2}$ at six stations (stations $1-7$ ) in the Kingston basin in 1997. Overall, the greatest change from 1964 to the present is a lake-wide decline in density of 
Fig. 4. Distribution and densities $\left(\right.$ no. $\cdot \mathrm{m}^{-2}$ ) of the mussel Dreissena spp. in 1997.
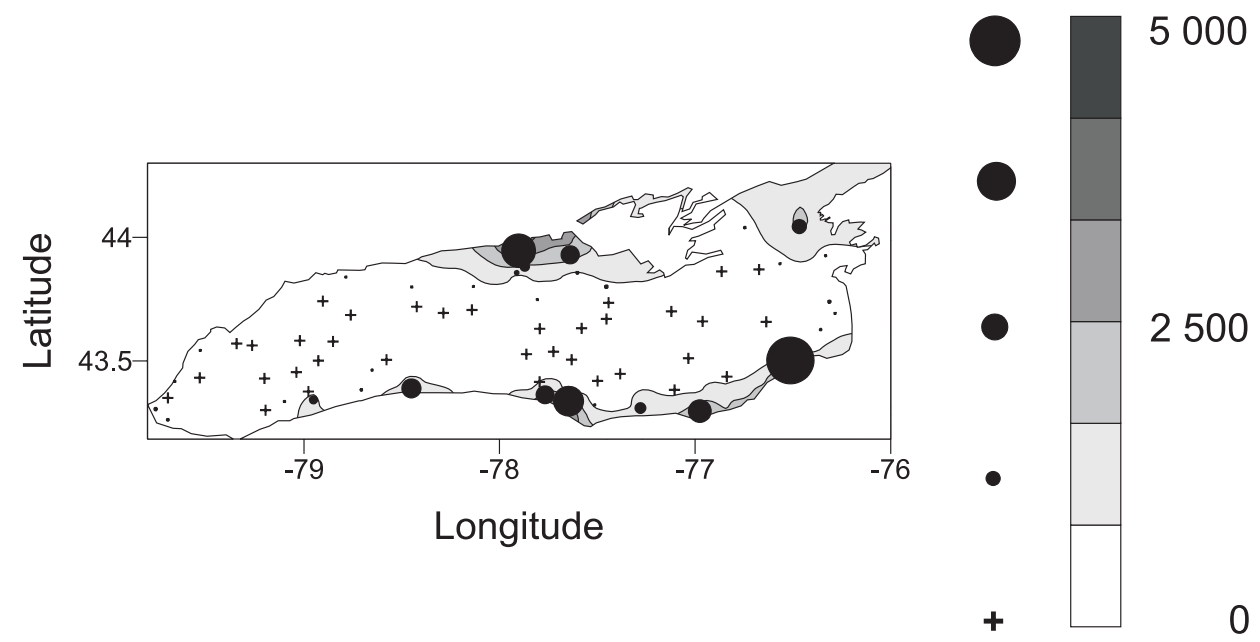

Table 5. Comparison between densities of three major benthic taxa found in 1964 (Hiltunen 1969), 1972 (Nalepa and Thomas 1976), 1994 and 1997 (present study) within three depth intervals.

\begin{tabular}{|c|c|c|c|c|}
\hline & 1964 & 1972 & 1994 & 1997 \\
\hline \multicolumn{5}{|l|}{ Depth 10-35 m } \\
\hline No. of stations & 14 & 22 & 4 & 16 \\
\hline Diporeia & $2122(815) \mathrm{a}$ & 2058 (598) a & $40(40) a b$ & $15(15) \mathrm{b}$ \\
\hline Oligochaeta & $8536(3203) \mathrm{a}$ & 9648 (3197) a & $2476(1186) a b$ & $856(280) b$ \\
\hline Sphaeriidae & $3223(641)$ a & 973 (275) b & 113 (40) bc & $109(42) \mathrm{c}$ \\
\hline \multicolumn{5}{|l|}{ Depth 36-91 m } \\
\hline No. of stations & 2 & 13 & 12 & 25 \\
\hline Diporeia & $9077(891) a b$ & 2131 (467) a & $4537(675) \mathrm{a}$ & $1281(405) b$ \\
\hline Oligochaeta & $2607(685)$ & $2382(816)$ & 983 (210) & $658(100)$ \\
\hline Sphaeriidae & $3697(262) \mathrm{a}$ & $107(48) b$ & $558(100)$ a & $233(81) b$ \\
\hline \multicolumn{5}{|l|}{ Depth >91 m } \\
\hline No. of stations & 8 & 20 & 35 & 27 \\
\hline Diporeia & $1250(356)$ & $793(141)$ & 1677 (169) & 1207 (162) \\
\hline Oligochaeta & 767 (128) a & $353(56) \mathrm{bc}$ & 405 (49) ab & $174(23) \mathrm{c}$ \\
\hline Sphaeriidae & $244(76) \mathrm{a}$ & 17 (12) b & $65(13) \mathrm{c}$ & $29(7) \mathrm{c}$ \\
\hline
\end{tabular}

Diporeia down to depths of $140 \mathrm{~m}$ and lower densities of all three taxa in the shallow depth interval (10-35 m) and the low-depositional zone.

After the invasion of Dreissena spp. into the Great Lakes, ecosystem changes included loss of edible particles (e.g., phytoplankton) and subsequent decline of phytoplankton consumers, diversion of material from the open water to surface sediments as bivalve tissue and biodeposits, and subsequent increase of benthic resources in and around mussel beds (Strayer et al. 1999; Haynes et al. 1999). The negative impact of Dreissena spp. on Diporeia and other benthic macroinvertebrate species is attributed to its high filtering capacity and large population densities. Since their introduction to Lake Ontario in 1988 or 1989, Dreissena populations have expanded, reaching densities of $82000 \cdot \mathrm{m}^{-2}$ in Lake Ontario by 1998 (Schaner 1998). Increased water clarity and declines in phytoplankton density are directly correlated with increased densities of Dreissena in Lake Erie and Lake Huron (Fahnenstiel et al. 1995). Mean densities of planktonic diatoms were reduced by $80-92 \%$ compared with pre- mussel periods in Hatchery Bay, western Lake Erie (Holland 1993). Although the reduction of diatom biomass could be the result of other system changes (e.g., reduced phosphorus loadings), concentrations of phosphorus in the open waters of Lake Ontario have remained approximately $10 \mu \mathrm{g} \cdot \mathrm{L}^{-1}$ since 1985 (Neilson et al. 1995).

Some of our results contrast those of Haynes et al. (1999), who found greater densities of Gammarid amphipods but no long-term changes in densities of oligochaetes and other species of macroinvertebrates at $7 \mathrm{~m}$ in cobble and artificial substrates after colonization by Dreissena in Lake Ontario. We found densities of three taxa to be lower in the lowdepositional zone and shallow water interval (10-35 m) of Lake Ontario but species richness to be greater at stations where Dreissena were present. The diversion of algae, especially diatoms, from open waters to mussel beds and hard substrates and incorporated into bivalve tissue and biodeposits would benefit species that can use the shells for habitat and (or) biodeposits for food.

Changes in benthic populations in deep lakes have been 
Fig. 5. Comparison of the dreissenid densities calculated from regression analysis (dashed line) of 1997 data (open circles) and Bailey et al.'s (1999) estimates (solid line).

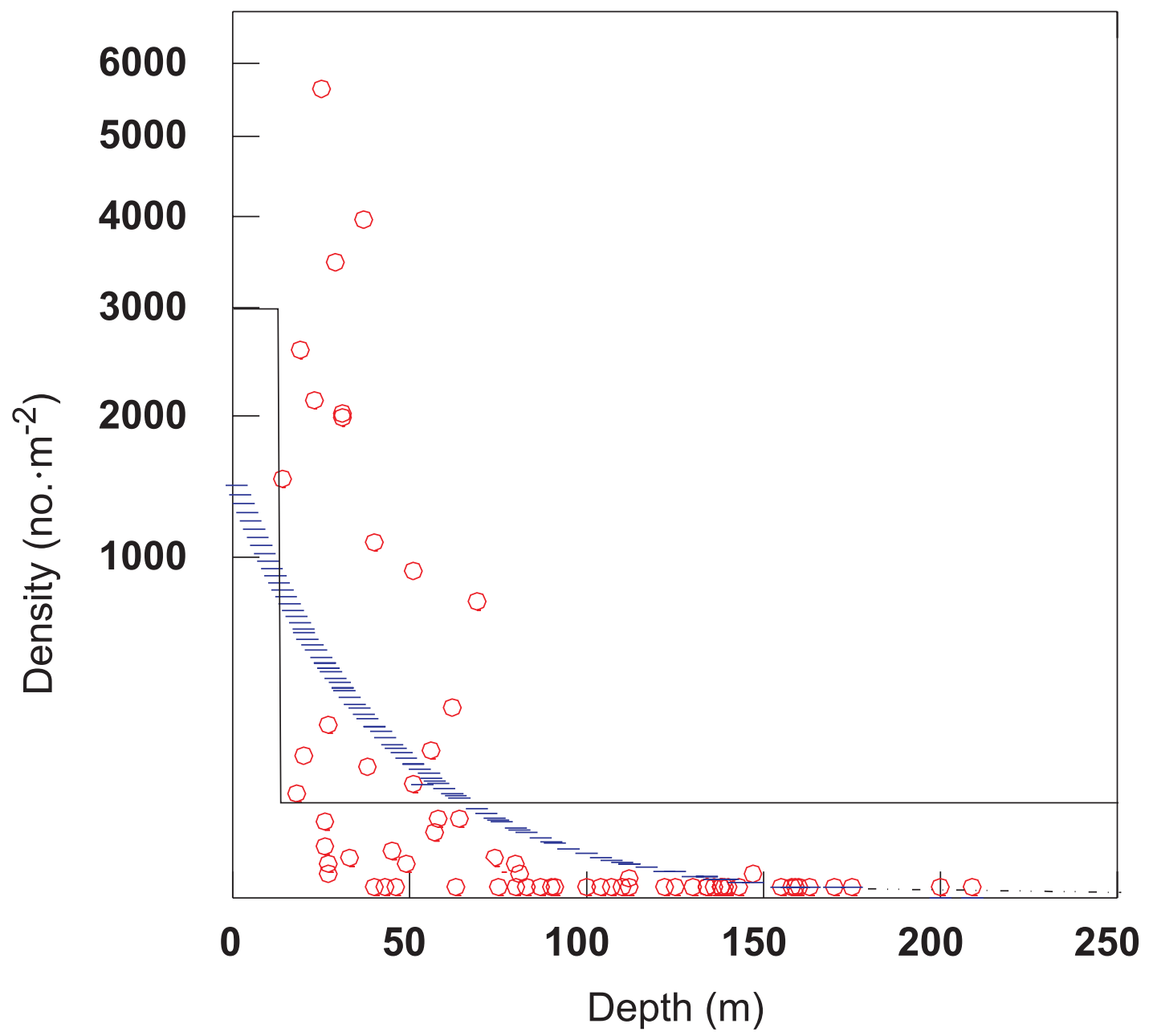

Table 6. Comparison of total turnover (days) at five depth intervals calculated with two dreissenid density estimates.

\begin{tabular}{llrrrr}
\hline & \multicolumn{7}{l}{ Depth intervals $(\mathrm{m})$} \\
\cline { 2 - 7 } Density estimates from & $0-15$ & $0-30$ & $0-45$ & $0-60$ & $0-75$ \\
\hline Bailey et al. (1999) & $0.1^{a}$ & 10.4 & 24.1 & 40.6 & 62.6 \\
1997 Ponar grabs & 0.4 & 2.4 & 7.4 & 19.3 & 51.4 \\
\hline
\end{tabular}

${ }^{a}$ Total turnover is a summation of area-weighted average of the depth intervals (Bailey et al. 1999).

attributed to trends in water column productivity (Saether 1980) because the density of the benthos is directly related to the amount of food material settling from the water column. Earlier studies have shown that the amphipod Gammarus fasciatus, a shallow water species $(<10 \mathrm{~m})$, increased after invasion of mussels in southwestern Lake Ontario (Stewart and Haynes 1994; Haynes et al. 1999). The authors suggested that Gammarus fasciatus growth is facilitated by the additional food source from pseudofeces/feces deposited by Dreissena and additional habitat provided by mussel shells. Unlike Gammarus, Diporeia does not actively feed on Dreissena fecal pellets (Lydy and Landrum 1993). It has been shown that Diporeia is a discriminating feeder re- quiring a high quality food in the spring (diatoms) to complete its life cycle (Dermott and Corning 1988; Gardner et al. 1985). The inability of Diporeia to use Dreissena biodeposits as a food source and the reduction in its original food source may have contributed to its decline. The large decline in densities of Diporeia and other benthic macroinvertebrates in Lake Ontario was most pronounced near areas where dreissenids were most abundant and we postulate that these declines could have resulted from a redirection of energy from open waters to Dreissena beds.

Recent changes in densities of benthic macroinvertebrates after invasion of Dreissena are not restricted to Lake Ontario. Dramatic declines of Diporeia in deeper waters of eastern Lake Erie also coincided with colonization by dreissenids (Dermott and Kerec 1997). Mean densities of Diporeia declined from $1844 \cdot \mathrm{m}^{-2}$ in 1979 to $218 \cdot \mathrm{m}^{-2}$ in 1993; Diporeia was found at all 13 deepwater stations in 1979 but only five stations in 1993. Dermott and Kerec (1997) suggest that competition for diatoms between Dreissena and Diporeia led to the exclusion of amphipods from areas where Dreissena was abundant. In southern Lake Michigan, Nalepa et al. (1998) reported declines of Diporeia, Oligochaeta, and Sphaeriidae. Declines in oligochaetes and sphaeriids occurred uniformly throughout the 
nearshore region $(<50 \mathrm{~m})$, whereas declines of Diporeia were greatest in the southeastern region of the lake. The region where Diporeia declined more than 60\% between 1980 and 1993 corresponded to areas where Dreissena was found in largest numbers. Nalepa et al. (1998) also hypothesized that the filtering activities of $D$. polymorpha were having a negative impact on Diporeia.

In Lake Ontario, Diporeia populations are declining even in areas with low dreissenid densities. Dreissena are not present in large numbers at depths greater than $40 \mathrm{~m}$; greatest densities occur in waters less than $30 \mathrm{~m}$. We hypothesize that filtering capacity of dreissenids may be enhanced and the reduction of Diporeia densities may be partially explained by the seasonal occurrence of isolated water masses in nearshore areas of the lake. The formation of a thermal bar in spring and early summer isolates nearshore waters from offshore waters. The progression of the thermal bar from areas near the shoreline to deeper waters $(>100 \mathrm{~m})$ usually begins in March and ends with the formation of the summer thermocline (Thomas et al. 1972). During the spring diatom bloom, diatoms shoreward of the thermal bar are exposed to warmer, nutrient-rich water and, because the waters are well mixed, are also exposed to the filtering activity of Dreissena, thus allowing Dreissena to intercept diatoms before they settle on deeper sediments. Scavia and Bennett (1980) used field observations and simulation models to demonstrate the relative importance of vertical mixing and in situ production to observed nutrient and algal biomass in Lake Ontario. During the spring, increased algal production occurs on the shoreward side of the $4^{\circ} \mathrm{C}$ isotherm (Stadelmann et al. 1974). The impact of dreissenids in the spring is directly related to their filtering capacity.

The seasonal impact of dreissenids was assessed by estimating their filtering capacity in comparison to volumes of water isolated by the thermal bar. Bailey et al.'s (1999) filtration model was used to calculate total turnover times (in days) at different depth intervals as

$$
T=\sum_{i=1}^{S}\left[p_{i} \cdot v_{i}\right] /\left[f \cdot a_{i} \cdot x_{i}\right]
$$

where $p_{i}$ is the proportion of total bottom area in stratum $i, v_{i}$ is the volume of stratum $i, f$ is the filtering rate of an average-sized mussel $\left(100 \mathrm{~mL} \cdot \mathrm{h}^{-1} \cdot\right.$ mussel $\left.^{-1}\right), a_{i}$ is the area of bottom in stratum $i$, and $x_{i}$ is the density of mussels in stratum $i$. Total turnover times were estimated from dreissenid densities used by Bailey et al. (1999) and from Ponar data collected in 1997 (Fig. 5). To obtain total turnover times, we needed dreissenid densities at 1-m intervals; therefore, we used regression analysis of dreissenid densities on depth to find these values, i.e.,

$$
\log \left(x_{i}\right)=7.335-0.045 \cdot d_{i}
$$

where $d_{i}$ represents depth at stratum $i$. We found that total turnover times were similar for depth intervals less than $30 \mathrm{~m}$ but much smaller based on our dreissenid estimates at depth intervals between 30 and $75 \mathrm{~m}$ (Table 6). At depth intervals greater than $80 \mathrm{~m}$, Bailey et al.'s (1999) total turnover times were substantially lower that those calculated from our estimates of dreissenid densities. It is clear that better estimates of dreissenid densities must be made before we can determine the true potential effect of dreissenid filtering on algal biomass in the spring. However, if our model and density estimates are fairly accurate, isolated water masses in Lake Ontario could be turned over in less than 10 days when the thermal bar is located at depth contours of $60 \mathrm{~m}$ or less.

The loss of Diporeia from large areas of Lake Ontario may be affecting fish production. Prey fish species such as slimy sculpin use Diporeia as a key food source in Lake Ontario (Owens and Weber 1995). Recently, there has been a decline in populations of this fish species in U.S. waters; estimates of densities of slimy sculpins have declined by $95 \%$ between the late 1980s and 1996 (New York Department of Environmental Conservation Annual Report 1998). Hoyle et al. (1999) found a sharp decline in both densities and body condition of lake trout and lake whitefish from the eastern region of the lake (Kingston basin) after 1990, which corresponds to the time that Diporeia were disappearing. In the past, the Kingston basin had produced the largest fish yields and supported a number of important commercial and sport fisheries. In 1997, a single specimen of Diporeia was collected from a total of 18 Ponar grab samples in the Kingston basin, where mean densities of Diporeia reached levels of $14000 \cdot \mathrm{m}^{-2}$ before the invasion of Dreissena.

In summary, the status of the benthic macroinvertebrate community of Lake Ontario has changed during the last 10 years. Densities of Diporeia, Oligochaeta, and Sphaeriidae have declined in soft substrate habitats of deep water, whereas dreissenid populations have increased in both hard and soft sediments. A zone of very low Diporeia density $(<4$ individuals $\cdot \mathrm{m}^{-2}$ ) extends as far as $26 \mathrm{~km}$ offshore and as deep as $200 \mathrm{~m}$, encompassing over $40 \%$ of the total surface area of Lake Ontario soft sediments sampled in 1997. The reduction of benthos, especially populations of Diporeia, in the nearshore of Lake Ontario is expected to have a major impact on the upper trophic levels of the lake.

\section{Acknowledgments}

The authors appreciate the contributions of the following people: Randy Braun, Ellen Heath, John Bourbon, Fred Luckey, Floyd Boettcher, Gary Phipps, Jim Gangl, Dennis McChesney, Joseph Hudek, James Kurtenbach, Alice Yeh, and Kathleen Savino for their support during the field operations; Tony Olsen and Don Stevens for statistical comments; and John Brazner and Anett Trebitz for helpful comments. Finally, the CJFAS Editors and anonymous reviewers provided helpful comments.

\section{References}

Ankley, G.T., Benoit, D.A., Hoke, R.A., Leonard, E.N., West, C.W., Phipps, G.L., Mattson, V.R., and Anderson, L.A. 1993. Development and evaluation of test methods for benthic invertebrates and sediments: effects of flow rate and deeding on water quality and exposure conditions. Arch. Environ. Contam. Tox. 25: $12-19$.

ASTM. 1991. Standard guide for collection, storage, characterization, and manipulation of sediments for toxicological testing. In ASTM 1993 Annual Book of Standards. Vol. 11.04, E1391-90. American Society for Testing and Materials, Philadelphia, Pa. pp. $79-85$.

Bailey, R.C., Grapentine, L., Stewart, T.J., Schaner, T., Chase, M.E., 
Mitchell, J.S., and Coulas, R.A. 1999. Dreissenidae in Lake Ontario: impact assessment at the whole lake and Bay of Quinte spatial scales. J. Great Lakes Res. 25: 482-491.

Cook, D.G., and Johnson, M.C. 1974. Benthic macroinvertebrates of the St. Lawrence - Great Lakes. Can. J. Fish. Aquat. Sci. 31: 763-783.

Dermott, R., and Corning, K. 1988. Seasonal ingestion rates of Pontoporeia hoyi (Amphipoda) in Lake Ontario. Can. J. Fish. Aquat. Sci. 45: 1886-1895.

Dermott, R., and Kerec, D. 1997. Changes to the deepwater benthos of eastern Lake Erie since the invasion of Dreissena: 1979-1993. Can. J. Fish. Aquat. Sci. 54: 922-930.

Fahnenstiel, G.L., Lang, G.A., Nalepa, T.F., and Johengen, T.H. 1995. Effects of zebra mussel (Dreissena polymorpha) colonization on water quality parameters in Saginaw Bay, Lake Huron. J. Great Lakes Res. 21: 435-448.

Fitzgerald, S.A., and Gardner, W.S. 1993. An algal carbon budget for pelagic-benthic coupling in Lake Michigan. Limnol. Oceanogr. 38: 547-560.

Flint, R.W. 1986. Hypothesized carbon flow through the deepwater Lake Ontario food web. J. Great Lakes Res. 12: 344-354.

Gardner, W.S., Nalepa, T.F., Frez, W.A., Cichocki, E.A., and Landrum, P.F. 1985. Seasonal patterns in lipid content of Lake Michigan macroinvertebrates. Can. J. Fish. Aquat. Sci. 42: 1827-1832.

Haynes, J.M., Stewart, T.W., and Cook, G.E. 1999. Benthic macroinvertebrate communities in southwestern Lake Ontario following invasion of Dreissena: continuing change. J. Great Lakes Res. 25: $828-838$

Hiltunen, J.K. 1969. The benthic macrofauna of Lake Ontario. Great Lakes Fish. Comm. Tech. Rep. 14: 39-50.

Holland, R.E. 1993. Changes in planktonic diatoms and water transparency in Hatchery Bay, Bass Island Area, western Lake Erie since the establishment of the zebra mussel. J. Great Lakes Res. 19: $617-624$.

Hoyle, J.A., Schaner, T., Casselman, J.M., and Dermott, R. 1999. Changes in lake whitefish (Coregonus clupeaformis) stocks in eastern Lake Ontario following Dreissena mussel invasion. Great Lakes Res. Rev. 4: 5-10.

Ingersoll, C.G., and Nelson, M.K. 1990. Testing sediment toxicity with Hyalella azteca (Amphipoda) and Chironomus riparius (Diptera). In Aquatic Toxicology in Risk Assessment, $13^{\text {th }}$ Symposium, ASTM STP 1096. Edited by W.G. Landis and W.H. van der Schalie. American Society for Testing Materials, Philadelphia, Pa. pp. 93-109.

Leach, J.H. 1993. Impacts of the zebra mussel (Dreissena polymorpha) on water quality and fish spawning reefs in western Lake Erie. In Zebra mussels: biology, impacts, and control. Edited by T.F. Nalepa and D.W. Schloesser. Lewis/CRC Press, Inc., Boca Raton, Fla. pp. 381-397.

Lydy, M.J., and Landrum, P.F. 1993. Assimilation efficiency for sediment sorbed benzo(a)pyrene by Diporeia spp. Aquat. Toxicol. 26: 209-223.

MacIsaac, H.J. 1996. Potential abiotic and biotic impacts of zebra mussels on inland waters of North America. Am. Zool. 36: 287-299.

Marzolf, G.R. 1965. Substrate relations of the burrowing amphipod Pontiporeia affinis in Lake Michigan. Ecology, 46: 579-592.

Mills, E.L., Dermott, R.M., Roseman, E.F., Dustin, D., Mellina, E., Conn, D.B., and Spidle, A.P. 1993. Colonization, ecology, and pop- ulation structure of the "quagga" mussel (Bivalvia: Dreissenidae) in the lower Great Lakes. Can. J. Fish. Aquat. Sci. 50: 2305-2314.

Mozley, S.C., and Howmiller, R.P. 1977. Environmental status of the Lake Michigan region: zoobenthos of Lake Michigan. Argonne National Lab. Rep. No. ANL/ES-40. Vol. 6. U.S. Energy Research and Development Administration. Argonne National Laboratory, Argonne, Ill.

Nalepa, T.F. 1991. Status and trends of the Lake Ontario macrobenthos. Can. J. Fish. Aquat. Sci. 48: 1558-1567.

Nalepa, T.F., and Thomas, N.A. 1976. Distribution of macrobenthic species in Lake Ontario in relation to sources of pollution and sediment parameters. J. Great Lakes Res. 2: 150-163.

Nalepa, T.F., Hartson, D.J., Fanslow, D.L., Lang, G.A., and Lozano, S.J. 1998. Decline in benthic macroinvertebrate populations in southern Lake Michigan, 1980-1993. Can. J. Fish. Aquat. Sci. 55: $2402-2413$

Neilson, M., L'Italien, S., Glumac, B., Williams, D., and Bertram, P. 1995. Nutrients: trends and system response. State of the Lakes Ecosystem Conference Background Paper, Environmental Canada and the United States Environmental Protection Agency, EPA 905-R-95-015. Great Lakes National Program Office, Chicago, Ill

New York Department of Environmental Conservation. 1998. 1997 Annual Report: Bureau of Fisheries, Lake Ontario Unit and St. Lawrence River Unit, to the Great Lakes Fisheries Commission's Lake Ontario Committee. Cape Vincent, N.Y.

Owens, R.W., and Weber, P.G. 1995. Predation on Mysis relicta by slimy sculpins (Cottus cognatus) in southern Lake Ontario. J. Great Lakes Res. 21: 275-283.

Saether, O. 1980. The influence of eutrophication on deep lake benthic invertebrate communities. Prog. Water Technol. 12: 161-180.

Scavia, D., and Bennett, J.R. 1980. Spring transition period in Lake Ontario- a numerical study of the causes of the large biological and chemical gradients. Can. J. Fish. Aquat. Sci. 37: 823-833.

Schaner, T. 1998. Zebra and quagga mussels. In Lake Ontario Management Unit 1997 Annual Report. Lake Ontario Management Unit Rep. ISSN 1201-8449. Ontario Ministry of Natural Resources, Picton, Ont.

Stadelmann, P., Moore, J.E., and Pickett, E. 1974. Primary productivity in relation to temperature structure, biomass concentration, and light conditions at an inshore and offshore station in Lake Ontario. Can. J. Fish. Aquat. Sci. 31: 1215-1232.

Stevens, D.L., Jr. 1997. Variable density grid-based sampling designs for continuous spatial populations. Environmetrics, 8: 167-195.

Stewart, T.W., and Haynes, J.M. 1994. Benthic macroinvertebrate communities of southwestern Lake Ontario following invasion of Dreissena. J. Great Lakes Res. 20: 479-493.

Strayer, D.L., Caraco, N.F., Cole, J.J., Findlay, S., and Pace, M.L. 1999. Transformation of freshwater ecosystems by bivalves. BioScience, 49: 19-27.

Thomas, R.L., Kemp, A.L.W., and Lewis, C.F.M. 1972. Distribution, composition, and characteristics of the surficial sediments of Lake Ontario. J. Sediment Petrol. 46: 66-84.

Wilkinson, L. 1996. SYSTAT 6.0 for Windows. SPSS Inc., Chicago, Ill. 